\title{
Comparative leukocyte blood profile of Emys orbicularis (Reptilia: Emydidae) from two populations
}

\author{
E. B. Romanova ${ }^{1 凶}$, I. A. Stolyarova ${ }^{1}$, A. G. Bakiev ${ }^{2}$, R. A. Gorelov ${ }^{2}$ \\ ${ }^{1}$ Lobachevsky State University of Nizhni Novgorod \\ 23 Gagarin Avenue, Nizhni Novgorod 603950, Russia \\ ${ }^{2}$ Samara Federal Research Center of RAS, \\ Institute of Ecology of the Volga River Basin of Russian Academy of Sciences \\ 10 Komzina St., Togliatti 445003, Russia
} Article info
Original Article
https://doi.org/10.18500/1814-6090-2021-21-
1-2-30-42

Received 7 February 2021, revised 4 March 2021, accepted 28 March 2021

\begin{abstract}
A comparative estimation of the leukocyte profile of the marsh turtle Emys orbicularis (Linnaeus, 1758) living in the Ural river basin (Orenburg region, Belyaevsky district, 11 females and 5 males) and in the Volga river basin (Astrakhan region, Krasnoyarsk district, 28 females and 20 males) was made. The blood formula (WBC) of males and females was calculated together with the calculation of integral leukocytal indices (the lymphocyte-granulocyte index, the leukocyte shift index, the heterophile/lymphocyte ratio, the heterophil/eosinophil ratio, and the lymphocyte/eosinophil ratio). Lymphocytes were the predominant leukocyte cells in the peripheral blood of Emys orbicularis (40-45\%). Among granulocytes, heterophiles (the population from the Orenburg region) or basophils (the population from the Astrakhan region) predominated. The absence of any differences in the quantitative indicators of the blood formula and integral indices for males and females indicated a comparable level of impact and identity of the physiological adaptation mechanisms occurring in the animals in the Orenburg region. Intersexual differences were manifested in an increased content of monocytes $(u=3.13$, $p=0.001$ ), which indicated activation of the natural immunity of males in comparison with females from the Astrakhan region. The leukocyte composition of the Emys orbicularis blood differed in the content of granulocytes and agranulocytes in different populations. The males from the Orenburg region differed from those from the Astrakhan region by an increased proportion of heterophiles and a reduced content of basophils. Females differed in all blood count parameters, except for eosinophils whose fraction was equal $(u=0.71, p=1.00)$. In the peripheral blood of females from the Orenburg region, a higher content of heterophiles, monocytes and a lower content of basophils and lymphocytes were found in comparison with those from the Astrakhan region. Quantitative-qualitative changes were detected in the leukocyte composition of the blood during the invasion of hemoparasites. The specific immune response (the content of lymphocytes) decreased, and the nonspecific defense system (the content of heterophiles) increased. The maintenance of the immunological reactivity of the organism under the conditions of invasion was determined by the functional activity of heterophiles, which was confirmed by a higher value of the heterophil/lymphocyte index. The blood formula (WBC) and the dynamics of leukocytal indexes of Emys orbicularis reflected the active response of the organism to a complex of environmental factors, including parasitic invasions.
\end{abstract}

Keywords: Emys orbicularis, leukocytal index, peripheral blood, WBC (white blood cells), Orenburg region, Astrakhan region

For citation: Romanova E. B., Stolyarova I. A., Bakiev A. G., Gorelov R. A. Comparative leukocyte blood profile of Emys orbicularis (Reptilia: Emydidae) from two populations. Current Studies in Herpetology, 2021, vol. 21, iss. 1-2, pp. 30-42 (in Russian). https://doi.org/10.18500/ 1814-6090-2021-21-1-2-30-42
This article is an open access article tions of the Creative Commons Attribution 4.0 License of Dagestan. Izvestia of Samara Scientific Center of the Russian Academy of Sciences, 2017, vol. 19, no. 2 (2), pp. 220-223 (in Russian).

Bolshakova O. E., Bakiev A. G. Viprocytes in the blood of reptiles of the Volga basin (preliminary report). gomedkamilova R. I. Acid and osmotic resistance of erythrocytes in blood of various populations of Emys orbicularis

\footnotetext{
Corresponding author. Department of Ecology of Institute of Biology and Biomedicine, Lobachevsky State University of Nizhni Novgorod, Russia.

ORCID and e-mail addresses: Elena B. Romanova: https://orcid.org/0000-0002-1925-7864, romanova@ibbm.unn.ru; Irina A. Stolyarova: irinaisto75@gmail.com; Andrey G. Bakiev: https://orcid.org/0000-0002-0338-2740, herpetology@list.ru; Roman A. Gorelov: https://orcid.org/00000002-0207-2951, gorelov.roman@mail.ru.
} 
Problems of Herpetology and Toxinology, 2005, iss. 8, pp. 5-7 (in Russian).

Vasiliev D. B. Veterinarnaya gerpetologiya [Veterinary Herpetology]. Moscow, Akvarium-Print Publ., 2016. 420 p. (in Russian).

Galaktionov V. G. Immunologiia [Immunology]. Moscow, Izdatel'skii tsentr "Akademiia»", 2004. 528 p. (in Russian).

Duysebaeva T. N., Doronin I. V., Malakhov D. V., Kukushkin O. V., Bakiev A. G. GIS analysis of the distribution and habitat of Emys orbicularis orbicularis (Testudines, Emydidae): Methodological aspects. Proceedings. Volga Region. Natural Sciences, 2019, no. 1, pp. 28-40 (in Russian).

Loboda E. I. Morphological and cytochemical characteristics of white blood cells in representatives of some species of cold-blooded vertebrates. Vestnik Zoologii, 1998, vol. 32, no. 3, pp. 54- 57 (in Russian).

Mkrtchyan Z. A. Materials for the study of blood parasites of reptiles in Armenia. Biologicheskij zhurnal Armenii, 1966, vol. XIX, no. 10, pp. 92-100 (in Russian).

Sokolina F. M., Pavlov A. V., Yusupov R. Gematologiia presmykaiushchikhsia. Metodicheskoe posobie $k$ kursu gerpetologii, bol'shomu praktikumu i seminaram [Reptile Hematology: The Guidance Manual for Herpetology Course, Long-Term Practical Work, and Seminars]. Kazan, Kazanskii universitet Publ., 1997. 31 p. (in Russian).

Khairutdinov I. Z., Sokolina F. M. Kharakteristika krovi reptilii i ee sviaz's usloviiami sredy obitaniia [Reptile Blood Characteristics and their Connection with Environmental Conditions]. Kazan, Kazanskii universitet Publ., 2010. 44 p. (in Russian).

Alder A., Huber E. Untersuchungen über Blutzellen and Zellbildung bei Amphibien und Reptilien. Folia Haematologica, 1923, Bd. 29, S. 1-22.

Alleman A. R., Jacobson E. R., Raskin R. E. Morphologic and cytochemical characteristics of blood cells from the desert tortoise (Gopherus agassizii). American Journal of Veterinary Research, 1992, vol. 53, pp. 16451651.

Arikan H., Cicek K. Morphology of peripheral blood cells from various species of Turkish herpetofauna. Acta Herpetologica, 2010, vol. 5, no. 2, pp. 179-198.

Arican H., Cicek K. Haematology of amphibians and reptiles: A review. North-Western Journal of Zoology, 2014, vol. 10, iss. 1, pp. 190-209.

Bolten A. B., Bjorndal K. A. Blood profilies for a wild population of green turtles (Chelonia mydas) in the southern Bahamas: Size-specific and sex-specific relationships. Journal of Wildlife Diseases, 1992, vol. 28, pp. 407-413.

Campbell T. W. Clinical pathology of reptiles. In: D. R. Mader, ed. Reptile Medicine and Surgery. St. Louis, MO, Saunders Elsevier, 2006, pp. 453-470.

Cicek K., Arikan H., Ayaz D. Blood cell morphology and erythrocytes count of two freshwater turtles,
Emys orbicularis and Mauremys rivulata, from Turkey. Ecologia Balkanica, 2015, vol. 7, iss. 1, pp. 21-27.

Coico R., Sunshine G., Benjamini E. Immunology: A Short Course. Hoboken, Wiley-Liss Publications, 2003. $500 \mathrm{p}$.

Colagar H., Jafari N. Red blood cell morphology and plasma proteins electrophoresis of the European pond terrapin Emys orbicularis. African Journal of Biotechnology, 2007, vol. 6, no. 13, pp. 1578-1581.

Davis A. K., Maney D. L., Maerz J. C. The use of leukocyte profiles to measure stress in vertebrates: A review for ecologists. Functional Ecology, 2008, vol. 22, pp. 760-772.

Duguy R. Le cycle annuel des e'le'ments figure's dus sang chez Emys orbicularis L., Lacerta muralis Laur., et Natrix maura L. Bulletin de la Société Zoologique de France, 1967, vol. 92, pp. 23-37.

Hasbun C. R., Lawrence A. J., Naldo J., Samour J. H., Al-Ghais S. M. Normal blood chemistry of free-living green sea turtle Chelonia mydas from the United Arab Emirates. Comparative Haematology International, 1998, vol. 8, pp. 174-177.

International Guiding Principles for Biomedical Research Involving Animals. Geneva, Switzerland, Council for International Organization of Medical Sciences Publ., 2012. 4 p.

Javanbakht H., Vaissi S., Parto P. The morphological characterization of the blood cells in the three species of turtle and tortoise in Iran. Research in Zoology, 2013, vol. 3, no. 1, pp. 38-44.

Joos J., Kirchner M., Vamberger M., Kaviani M., Rahimibashar M. R., Fritz U., Muller J. Climate and patterns of body size variation in the European pond turtle, Emys orbicularis. Biological Journal of the Linnean Society, 2017, vol. 20, pp. 1-15.

Knotkova Z., Doubek J., Knotek Z., Hajkova P. Blood cell morphology and plasma biochemistry in Russian tortoises (Agrionemys horsfieldi). Acta Veterinaria, Brno, 2002, vol. 71, pp. 191-198.

Lenk P., Fritz U., Joger U., Wink M. Mitochondrial phylogeography of the European pond turtle, Emys orbicularis (Linnaeus, 1758). Molecular Ecology, 1999, vol. 8, iss. 11, pp. 1911-1922.

Lukakis J. J. A phylogenetic study on turtle hemoglobins. Comparative Biochemistry and Physiology. Part B: Biochemistry and Molecular Biology, 1974, vol. 48, pp. 231-240.

Lukakis J. J., Haritos A. A. Electrophoretic and antigenic properties of turtle myoglobins. Comparative Biochemistry and Physiology. Part B: Biochemistry and Molecular Biology, 1973, vol. 46, pp. 117-122.

Marcogliese D., Cone D. R. Parasite communities as indicators of ecosystem stress. Parassitologia, 1997, vol. 6, pp. 65-89.

Metin K., Türkozan O., Kargin F., Koca Y. B., Taskavak E., Koca S. Blood Cell Morphology and Plasma Biochemistry of the Captive European Pond Tur- 
tle Emys orbicularis. Acta Veterinaria, Brno, 2006, vol. 75 , iss. 1 , pp. $49-55$.

Molla S. H., Bandyopadhyay P. K., Gurelli G. On the Occurrence of a Haemogregarinae (Apicomplexa) Parasite from Freshwater Turtles of South 24 Parganas, West Bengal, India. Turkiye Parazitoloji Dergisi, 2013, vol. 37, pp. 118-122.

Musquera S., Massegú J., Planas J. Blood proteins in turtles (Testudo hermanni, Emys orbicularis and Caretta caretta). Comparative Biochemistry and Physiology. Part A: Physiology, 1976, vol. 55, pp. 225-230.

Olsen O. W. Animal Parasites: Their Life Cycles and Ecology. New York, Dover Publication, 1986. 564 p.

Özvegy J., Marinković D., Vučićević M., Gajić B., Stevanović J., Krnjaić D., Aleksić-Kovačević S. Cytological and molecular identification of Haemogregarina stepanowi in blood samples of the European pond turtle (Emys orbicularis) from quarantine at Belgrade Zoo. Acta Veterinaria, Beograd, 2015, vol. 65, iss. 4, pp. 443-453.

Palomeque J., Sesé P., Planas J. Respiratory properties of the blood of turtles. Comparative Biochemistry and Physiology. Part A: Physiology, 1977, vol. 57, pp. 479-483.

Perpinan D., Sanchez C. Morphologic and cytochemical characteristics of blood cells from the European pond turtle (Emys orbicularis) and mediterranean pond tur- tle (Mauremys leprosa). Journal of Herpetological Medicine and Surgery, 2009, vol. 19, no. 4, pp. 119-127.

Red List (Version 2020-3). 2020. Available at: https://www.iucnredlist.org/ (accessed 27 January 2020).

Siddall M. E. Desser S. S. Prevalence and intensity of Haemogregarina balli (Apicomplexa; Adeleina; Haemogregarinidae) in three turtle species from Ontario, with observations on interaerythrocytic development. Canadian Journal of Zoology, 1992, vol. 70, no. 1, pp. $123-128$.

Sypek J. P., Borysenko M., Findlay S. R. Antiimmunoglobulin induced histamine release from naturally abundant basophils in the snapping turtle, Chelydra serpentine. Developmental and Comparative Immunology, 1984, vol. 8, iss. 2, pp. 359-366.

Telford S. R. Hemoparasites of the Reptilia: Color Atlas and Text. Boca Raton, CRG Press, 2009. 376 p.

Uğurtaş I. H., Sevinç M., Yildirimhan H. S. 2003. Erythrocyte size and morphology of some tortoises and turtles fromTurkey. Zoological Studies, 2003, vol. 42, no. 1 , pp. $173-178$.

Vasse J., Beaupain D. Erythropoiesis and haemoglobin ontogeny in the turtle Emys orbicularis L. Journal of Embryology and Experimental Morphology, 1981, vol. 62, pp. 129-138. 